J. Clin. Chem. Clin. Biochem.

Vol. 23, 1985, pp. $631-636$

\title{
Plasma Pyridoxal 5'-Phosphate Concentrations in Relation to Apo-Aminotransferase Levels in Normal, Uraemic, and Post-Myocardial Infarct Sera
}

\author{
By A.M. Gressner and Daniela Sittel
}

Abteilung für Klinische Chemie und Zentrallaboratorium, Philipps-Universität Marburg/Lahn

(Received January 14/May 28, 1985)

\begin{abstract}
Summary: The concentrations of pyridoxal 5'-phosphate, and the holoenzyme activities and apoenzyme contents of alanine aminotransferase and aspartate aminotransferase in plasma were determined simultaneously in healthy individuals, patients with renal insufficiency with and without chronic haemodialysis and in patients with acute myocardial infarction. Plasma pyridoxal 5'-phosphate is significantly diminished in uraemic patients and in post-myocardial infarct sera, healthy females have lower pyridoxal $5^{\prime}$-phosphate levels $(26.2 \pm 9.0 \mathrm{nmol} / \mathrm{l})$ than healthy males $(41.0 \pm 15.1 \mathrm{nmol} / \mathrm{l})$. The stimulation in vitro of the activities of aspartate aminotransferase and alanine aminotransferase by addition of pyridoxal 5 '-phosphate $(0.1$ $\mathrm{mmol} / \mathrm{l}$ ) was found to be independent of the endogenous coenzyme level. In sera of uraemic patients without chronic haemodialysis an inverse statistic correlation between pyridoxal 5'-phosphate-induced stimulation of aspartate aminotransferase activity and the concentrations of urea $(r=-0.696)$ and creatinine $(r=-0.715)$ was found. The respective correlations are much weaker for alanine aminotransferase. The apoenzyme fraction was highest in post-myocardial infarct sera. Follow up of these patients did not reveal any relationship between the fluctuations of pyridoxal 5'-phosphate levels and apoenzyme contents of both alanine aminotransferase and aspartate aminotransferase. The results permit the conclusion that the degree of in vitro stimulation of aminotransferases by pyridoxal 5'-phosphate can not be predicted from the endogenous coenzyme level.
\end{abstract}

Pyridoxal-5'-phosphat-Konzentrationen im Plasma in Beziehung zu Apo-Aminotransferase-Gehalten in Sera normaler Probanden sowie von Patienten mit Urämie und nach Herzinfarkt

Zusammenfassung: Die Konzentrationen von Pyridoxal-5'-phosphat im Plasma sowie Holoenzymaktivitäten und Apoenzymgehalte von Alaninaminotransferase und Aspartataminotransferase im Serum wurden simultan bei gesunden Probanden, Patienten mit Niereninsuffizienz mit und ohne chronischer Hämodialyse und bei Patienten mit akutem Myokardinfarkt bestimmt. Pyridoxalphosphat im Plasma ist bei Patienten mit Urämie und nach Myokardinfarkt signifikant vermindert: gesunde weibliche Personen haben niedrigere Pyridoxal5 '-phosphat-Konzentrationen $(26,2 \pm 9,0 \mathrm{nmol} / \mathrm{l})$ als gesunde männliche Personen $(41,0 \pm 15,1 \mathrm{nmol} / \mathrm{l})$. Die in vitro Stimulation der katalytischen Aktivitäten beider Aminotransferasen durch Präinkubation mit 0,1 mmol/l (Endkonzentration) Pyridoxal-5'-phosphat erwies sich als unabhängig von der endogenen CoenzymKonzentration. Mit Sera von urämischen Patienten ohne chronische Hämodialyse ergab sich eine negative statistische Korrelation zwischen Pyridoxal-5'-phosphat-induzierter Stimulation der Aktivität von Aspartataminotransferase und den Konzentrationen von Harnstoff $(r=-0,696)$ und Kreatinin $(r=-0,715)$. Die diesbezüglichen Korrelationen sind für die Alaninaminotransferase wesentlich schwächer. Die Apoenzymfraktionen waren in Postmyokardinfarkt-Sera am höchsten. Verlaufskontrolluntersuchungen bei Myokardinfarktpatienten zeigten keine Beziehung zwischen den Fluktuationen der Pyridoxal-5'-phosphat-Konzentration und den Apoenzymgehalten beider Aminotransferasen. Aus den Ergebnissen wird geschlossen, daß der Grad der in vitro-Stimulation von beiden Aminotransferasen durch Pyridoxal-5'-phosphat nicht aus den endogenen Coenzymkonzentrationen vorhergesagt werden kann. 


\section{Introduction}

The aminotransferases, aspartate aminotransferase (EC 2.6.1.1) and alanine aminotransferase (EC 2.6.1.2), require the coenzyme, pyridoxal $5^{\prime}$-phosphate, for catalytic activity (1). The level of this active metabolite of vitamin $B_{6}$ in serum varies considerably, depending on nutritional status and the type of desease affecting a patient. Diminished plasma pyridoxal 5'-phosphate occurs, for example, in more than $50 \%$ of chronic alcoholics (2), in about $70 \%$ of patients with alcoholic liver cirrhosis (3), in patients with renal insufficiency and nonuraemic kidney transplant (4), and possibly also in otherwise healthy persons (5). Consequently, it has been shown in several studies that supplementation with pyridoxal 5'-phosphate of the assay for measuring the catalytic concentrations of both aminotransferases in serum results in enhanced activities, thus indicating the presence of appreciable amounts of apoaminotransferases in the circulation $(5-13)$. To avoid an underestimation of in vitro activities of both aminotransferases by endogenous deficiency of pyridoxal 5 '-phosphate a modification of the conventional assay (14) of both enzymes has been proposed by the International Federation of Clinical Chemistry (IFCC), in which the incubation mixture is supplemented with $0.1 \mathrm{mmol} / 1$ pyridoxal 5'-phosphate $(15,16)$. During a preincubation period of 7 minutes the apoenzyme fraction becomes saturated with the coenzyme and is thereby fully reactivated (17).

Both human and experimental studies point to significant differences in the degree of stimulation of both aminotransferases by added pyridoxal 5 '-phosphate (18). The type of injury and not necessarily the organ affected determines the degree of activation (19). Patients with various diseases show different increases in aspartate aminotransferase activity with added coenzyme $(20,21)$, and the mitochondrial isoenzyme of aspartate aminotransferase behaves differently from its cytosolic fraction (22). The quantitative differences in reactivation might be explained by variable levels of circulating apoaminotransferases, by structural changes of the apoenzyme fraction resulting in its partial inactivation, and/or unresponsiveness to added pyridoxal 5'-phosphate; or additional, unidentified factors may also be involved. To gain more insight in the mechanisms underlying the differences in reactivation, apoenzyme levels of the aminotransferases should be directly compared with actual concentrations of plasma pyridoxal 5'-phosphate. A recent study points to an inverse relationship between the stimulation of enzyme activity and pyridoxal 5'-phosphate concentration in plasma of healthy persons (23), but similar studies in diseased individuals are lacking. Therefore we determined the serum apoenzyme content of both aminotransferases in relation to the plasma pyridoxal 5'-phosphate concentration in healthy individuals, in patients with proven pyridoxal 5 '-phosphate deficiency and normal total aminotransferase activities (uraemic patients), and in patients having elevated aspartate aminotransferase activities (myocardial infarction). The results do not reveal a relationship between coenzyme level in plasma and apoaminotransferase content in serum.

\section{Materials and Methods}

\section{Materials}

Pyridoxal 5'-phosphate, apoenzyme of $L$-tyrosine decarboxylase $(1.1 \mathrm{U} / \mathrm{mg}$ ) (EC 4.1.1.25), and tyramine $\cdot \mathrm{HCl}$ were from Sigma Chem. Company, Munich, $\left[{ }^{3} \mathrm{H}\right]$ tyrosine (1998 $\mathrm{GBq} / \mathrm{mmol}=54 \mathrm{Ci} / \mathrm{mmol}$ ) was from New England Nuclear, Boston, USA.

\section{Patients}

Healthy persons (11 female and 11 male blood donors ranging from 20 to 40 years) served as a reference population. Patients with renal insufficiency $(n=46)$ were subdivided into those undergoing haemodialysis $(n=26)$ and those without dialysis $(n=20)$. Patients suffering from acute myocardial infarction $(n=12)$ were monitored with up to 6 consecutive measurements within 14 days after hospital admission.

Assay of aspartate aminotransferase and alanine aminotransferase

Venous blood was allowed to clot for 30 minutes, centrifuged and the catalytic concentrations of both enzymes were measured either immediately or after storage of the sera for $24 \mathrm{~h}$ at $4{ }^{\circ} \mathrm{C}$. Both enzyme activities were determined at $25^{\circ} \mathrm{C}$ according to the recommendations of the IFCC $(15,16)$ with pyridoxal 5 -phosphate in the incubation mixture (final concentration $0.1 \mathrm{mmol} / \mathrm{l}$, preincubation period $7.5 \mathrm{~min}$ ) and without pyridoxal 5 -phosphate under otherwise identical conditions, respectively. The reagents of the assays were from Boehringer Mannheim GmbH, FRG; the method was adapted to the Eppendorf ACP 5040 analyser. The accuracy of the assays was checked with Precipath $\mathrm{E}$, the precision from day to day with a pool serum. The coefficient of variation (CV) was about $4 \%$ (mean activity $20 \mathrm{U} / \mathrm{l}$ ) in the assays without addition of pyridoxal 5 =phosphate. The CV of pyridoxal $5^{\prime}$ phosphate-supplemented assays was lower at about $2 \%$.

Holoenzyme concentration is defined as the catalytic activity in the presence of pyridoxal 5'-phosphate; the difference between the enzyme activities with and without supplementation of pyridoxal $5^{\prime}$-phosphate reflects the apoenzyme level in serum; activation is the percentage increase of activity after addition of pyridoxal $S^{\prime}$-phosphate.

\section{Determination of pyridoxal 5'-phosphate}

About $5 \mathrm{ml}$ venous blood was collected in tubes containing potassium EDTA as an anticoagulap̣t, promptly chilled in ice 
and centrifuged at $2^{\circ} \mathrm{C}(1000 \mathrm{~g}, 10 \mathrm{~min})$ to obtain plasma. The plasma was diluted $1: 20$ with potassium acetate $(0.1 \mathrm{~mol} / \mathrm{l}, \mathrm{pH}$ $5.5)$ in which the concentration of pyridoxal 5'-phosphate was determined in duplicate by a slightly modified radioenzymatic procedure utilizing the stimulation of added tyrosine apodecarboxylase by endogenous pyridoxal 5'-phosphate (24). Briefly, $200 \mu \mathrm{l}$ of $1: 20$ diluted plasma was mixed with $200 \mu \mathrm{l} 0.1$ mol/l potassium acetate, $\mathrm{pH} 5.5$ and $100 \mu \mathrm{l}$ purified tyrosine apodecarboxylase $(10 \mathrm{~g} / 1$ potassium acetate, $\mathrm{pH} 5.5)(25)$, incubated for $30 \mathrm{~min}$ at $37^{\circ} \mathrm{C}$ in the dark, cooled at $0^{\circ} \mathrm{C}$ and reincubated for $1 \mathrm{~h}$ at $37^{\circ} \mathrm{C}$ after addition of $600 \mu \mathrm{l}\left[{ }^{3} \mathrm{H}\right]$ tyrosine $(74 \mathrm{GBq} / \mathrm{mol})(24)$. The reaction is terminated by additions of $2 \mathrm{ml}$ borate buffer $(0.5 \mathrm{~mol} / 1, \mathrm{pH} 10.5), 0.8 \mathrm{~g} \mathrm{NaCl}$, and $6 \mathrm{ml}$ ethyl acetate. The mixture is vigorously extracted for $20 \mathrm{~min}$, centrifuged $(10 \mathrm{~min}, 2000 \mathrm{~g})$ and $4 \mathrm{ml}$ of the upper layer is counted for $\left[{ }^{3} \mathrm{H}\right]$ tyramine in a liquid scintillation counter.

The amount of $\left[{ }^{3} \mathrm{H}\right]$ tyramine generated is proportional to the concentration of pyridoxal $5^{\prime}$-phosphate in the sample. The results were calculated from a standard curve ranging from 0.47 to $6.25 \mathrm{nmol} / 1$ pyridoxal $5^{\prime}$-phosphate in the assay. In each series the recovery of pyridoxal 5 -phosphate was checked and found to be between 87 and $109 \%$. The interassay coefficient of variation was $4.6 \%(\bar{x}=32.3 \mathrm{nmol} / \mathrm{l})$.

\section{Statistical analysis}

The statistical significance of differences was checked with Pitman's permutation test (26); significance is indicated by $\mathrm{p} \leqslant 0.05$.

\section{Results and Discussion}

Concentrations of pyridoxal 5'-phosphate in normal and diseased individuals

The mean concentration $\pm S$. D. of pyridoxal $5^{\prime}$ phosphate in plasma as determined by the radioenzymatic method is $33.6 \pm 14.3 \mathrm{nmol} / 1$ which is lower than that reported by others using different procedures (for a summary see l. c. (27)) but agrees well with the data reported by Camp et al. (24), applying an identical analytic principle, and others $(25,28)$. Male healthy individuals have significantly higher concentrations $(41.0 \pm 15.1 \mathrm{nmol} / \mathrm{l})$ than female persons $(26.2 \pm 9.0 \mathrm{nmol} / \mathrm{l})$ (fig. 1). The lower concentration of pyridoxal $5^{\prime}$-phosphate in women might be a consequence of the intake of oral contraceptive steroids (29). Patients suffering from renal insufficiency exhibit reduced mean plasma pyridoxal 5 -phosphate levels (15 nmol/l), which are similar in patients receiving and not receiving haemodialysis, thus confirming results of a previous report (4). An inverse statistic correlation between the concentrations of urea or creatinine and plasma pyridoxal $5^{\prime}$-phosphate is not evident $(r<0: 340)$. Also in patients with acute myocardial infarction a significant reduction of the concentration of plasma pyridoxal 5'-phosphate is found, which is comparable to that found in renal insufficiency (fig. 1).

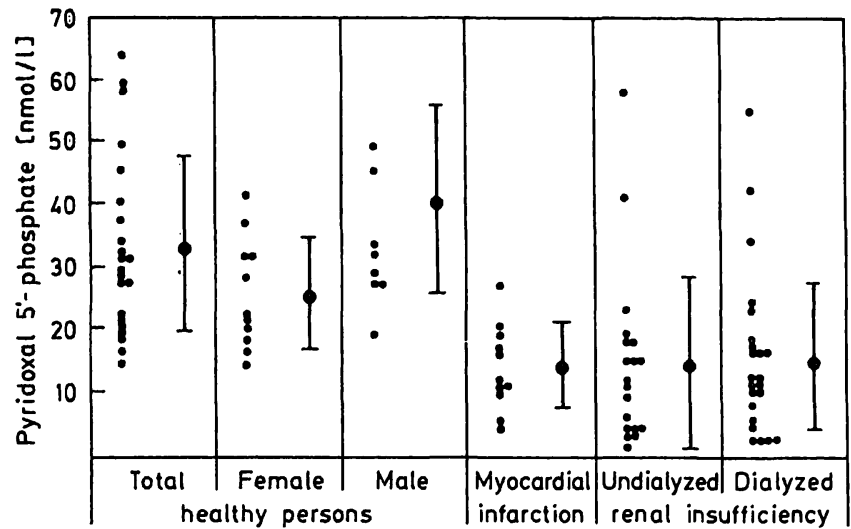

Fig. 1. Frequency distribution of the concentration of pyridoxal 5 -phosphate in plasma of healthy persons, patients with myocardial infarction and renal insufficiency with and without haemodialysis. Mean concentrations $\pm S$. D. of each group are given. The differences between femalc and male healthy persons and between total healthy persons and the various disease categories are statistically significant $(p \leqslant 0.01)$.

Apoenzyme contents and stimulation by pyridoxal 5'-phosphate of the catalytic activities of serum aminotransferases

As detailed in table 1 the mean activities of aspartate and alanine aminotransferase in healthy individuals and renal insufficiency patients are similar, whereas, as expected, in myocardial infarction a significant rise of aspartate aminotransferase and, less pronounced, of alanine aminotransferase is noticed. In healthy males and females apoenzyme contents of aspartate aminotransferase are 2.8 and $2.2 \mathrm{U} / \mathrm{l}$, respectively, amounting 14.2 and $12.0 \%$ of holoenzyme activity. Apoenzyme activities and contents of alanine aminotransferase show a moderate, but statistically insignificant elevation in female persons compared with males. This difference might be a reflection of the lower concentration of pyridoxal 5'-phosphate in plasma of females than in males reported above. If this explanation holds true aspartate aminotransferase activity in female persons exhibits either a greater unresponsiveness to exogenous pyridoxal 5 -phosphate than alanine aminotransferase or the saturation levels with the coenzyme of both aminotransferases in serum are different and not strictly dependent on the concentration of pyridoxal 5'-phosphate in blood. This assumption is in line with previous findings, which show a much more pronounced decrease of alanine aminotransferase than of aspartate aminotransferase activities in liver and serum of pyridoxine-deficient rats (18). Thus, the apparent greater fraction of apoenzyme of alanine aminotransferase in females could be due to a greater sensitivity of this enzyme to a decrease of systemic pyridoxalphosphate. 
Tab. 1. Catalytic concentrations of aspartate aminotransferase and alanine aminotransferase in the absence and presence of added pyridoxal 5'-phosphate (PLP, final concentration $0.1 \mathrm{mmol} / \mathrm{l}$ ) in sera of healthy persons, patients with renal insufficiency and patients with myocardial infarction. Apoenzyme is calculated from the difference between holoenzyme catalytic concentration (in the presence of added PLP) and catalytic activity concentration without added PLP and is expressed as fraction of holoenzyme catalytic concentration.

\begin{tabular}{|c|c|c|c|c|c|c|}
\hline \multirow[t]{2}{*}{ Group } & \multirow[t]{2}{*}{ Parameter } & & \multicolumn{2}{|c|}{$\begin{array}{l}\text { Aspartate } \\
\text { aminotransferase }\end{array}$} & \multicolumn{2}{|c|}{$\begin{array}{l}\text { Alanine } \\
\text { aminotransferase }\end{array}$} \\
\hline & & & Mean value & S. D. & Mean value & S. D. \\
\hline $\begin{array}{l}\text { All healthy persons } \\
(n=22)\end{array}$ & $\begin{array}{l}\text { Without PLP } \\
\text { With PLP } \\
\text { Difference } \\
\text { Apoenzyme fraction }\end{array}$ & $\begin{array}{l}(\mathrm{U} / \mathrm{l}) \\
(\mathrm{U} / \mathrm{l}) \\
(\mathrm{U} / \mathrm{l})\end{array}$ & $\begin{array}{l}16.2 \\
18.7 \\
+2.5 \\
0.131\end{array}$ & $\begin{array}{c}2.9 \\
2.9 \\
+1.7 \\
0.091\end{array}$ & $\begin{array}{l}14.2 \\
15.7 \\
+1.5 \\
0.113\end{array}$ & $\begin{array}{l}4.7 \\
6.6 \\
2.9 \\
0.080\end{array}$ \\
\hline $\begin{array}{l}\text { Male healthy persons } \\
(n=11)\end{array}$ & $\begin{array}{l}\text { Without PLP } \\
\text { With PLP } \\
\text { Difference } \\
\text { Apoenzyme fraction }\end{array}$ & $\begin{array}{l}(U / 1) \\
(U / 1) \\
(U / 1)\end{array}$ & $\begin{array}{l}16.6 \\
19.5 \\
+2.8 \\
0.142\end{array}$ & $\begin{aligned} & 2.3 \\
& 2.8 \\
&+ 1.1 \\
& 0.048\end{aligned}$ & $\begin{array}{l}14.6 \\
16.0 \\
+1.4 \\
0.089\end{array}$ & $\begin{array}{l}3.4 \\
3.6 \\
1.1 \\
0.066\end{array}$ \\
\hline $\begin{array}{l}\text { Female healthy persons } \\
(n=11)\end{array}$ & $\begin{array}{l}\text { Without PLP } \\
\text { With PLP } \\
\text { Difference } \\
\text { Apoenzyme fraction }\end{array}$ & $\begin{array}{l}(U / 1) \\
(U / 1) \\
(U / 1)\end{array}$ & $\begin{array}{c}15.8 \\
18.0 \\
+2.2 \\
0.120\end{array}$ & $\begin{aligned} & 3.4 \\
& 2.9 \\
&+ 2.2 \\
& 0.122\end{aligned}$ & $\begin{array}{l}14.0 \\
16.5 \\
+2.5 \\
0.143\end{array}$ & $\begin{aligned} & 5.7 \\
& 7.1 \\
&+ 1.8 \\
& 0.076\end{aligned}$ \\
\hline $\begin{array}{l}\text { Renal insufficiency, dialysed } \\
(\mathrm{n}=26)\end{array}$ & $\begin{array}{l}\text { Without PLP } \\
\text { With PLP } \\
\text { Difference } \\
\text { Apoenzyme fraction }\end{array}$ & $\begin{array}{l}(\mathrm{U} / \mathrm{l}) \\
(\mathrm{U} / \mathrm{l}) \\
(\mathrm{U} / \mathrm{l})\end{array}$ & $\begin{array}{r}14.1 \\
13.5 \\
-0.6 \\
-\end{array}$ & $\begin{array}{l}4.3 \\
4.8 \\
2.9 \\
-\end{array}$ & $\begin{array}{c}13.3 \\
16.0 \\
+2.7 \\
0.111\end{array}$ & $\begin{array}{l}6.9 \\
9.4 \\
4.9 \\
0.255\end{array}$ \\
\hline $\begin{array}{l}\text { Renal insufficiency, undialysed } \\
(n=20)\end{array}$ & $\begin{array}{l}\text { Without PLP } \\
\text { With PLP } \\
\text { Difference } \\
\text { Apoenzyme fraction }\end{array}$ & $\begin{array}{l}(U / 1) \\
(U / 1) \\
(U / 1)\end{array}$ & $\begin{array}{r}15.8 \\
14.1 \\
-1.7 \\
-\end{array}$ & $\begin{array}{l}4.9 \\
3.7 \\
1.7 \\
-\end{array}$ & $\begin{array}{c}12.9 \\
14.7 \\
+1.8 \\
0.099\end{array}$ & $\begin{array}{l}4.0 \\
5.6 \\
2.2 \\
0.118\end{array}$ \\
\hline $\begin{array}{l}\text { Myocardial infarction } \\
(n=12)\end{array}$ & $\begin{array}{l}\text { Without PLP } \\
\text { With PLP } \\
\text { Difference } \\
\text { Apoenzyme fraction }\end{array}$ & $\begin{array}{l}(\mathrm{U} / \mathrm{l}) \\
(\mathrm{U} / \mathrm{l}) \\
(\mathrm{U} / \mathrm{l})\end{array}$ & $\begin{array}{c}108.0 \\
145.0 \\
+37.0 \\
0.260\end{array}$ & $\begin{array}{l}34.0 \\
13.0 \\
10.0 \\
0.090\end{array}$ & $\begin{array}{c}34.0 \\
40.0 \\
+6.0 \\
0.150\end{array}$ & $\begin{array}{l}15.0 \\
12.0 \\
3.0 \\
0.090\end{array}$ \\
\hline
\end{tabular}

Whereas this explanation might be valid for the differences noticed between healthy males and females, different mechanisms are effective in patients with renal insufficiency. It is of great interest that pyridoxal 5'-phosphate is not able to stimulate aspartate aminotransferase activity in uraemic patients undergoing chronic haemodialysis (tab. 1). In fact, mean activity is slightly inhibited by adding the coenzyme and, by this criterion, an apoenzyme fraction of aspartate aminotransferase is not detectable, although these patients have a significantly reduced plasma pyridoxal 5'-phosphate concentration (fig. 1). Undialysed uraemic patients have slightly higher apoenzyme levels than dialysed patients in spite of similar pyridoxal 5'-phosphate levels. In both groups of patients only a small apoenzyme fraction of alanine aminotransferase, not different from that in normal patients, was measured (tab. 1).

A statistic correlation between pyridoxal 5 -phosphate concentrations in plasma and apoaminotransferase contents is not evident in normal individuals $(r=-0.102)$ or in uraemic patients, either undialysed $(r=-0.310)$ or dialysed $(r=0.095)$. It is noteworthy that in uraemic patients without chronic haemodialysis an inverse statistic correlation exists between pyridoxal 5'-phosphate-induced stimulation of aspartate aminotransferase activity and the concentration of urea $(r=-0.696)$ and creatinine $(r=$ -0.715 ) (fig. 2). With respect to the pyridoxal 5'phosphate-dependent stimulation of alanine aminotransferase the correlation was much weaker, i. e. $r=-0.276$ for urea and $r=-0.330$ for creatinine (fig. 2). Patients subjected to haemodialysis did not exhibit a statistic correlation between these parameters.

Taken together the results demonstrate that in uraemic patients no statistically evident interdependence between the plasma level of pyridoxal $5^{\prime}$ phosphate and the degree of pyridoxal $5^{\prime}$-phosphateinduced activation of aspartate aminotransferase and alanine aminotransferase exists. In fact, in sera of patients with renal insufficiency, addition of pyridoxal 5'-phosphate to the assay results in a small but insignificant inhibition of aspartate aminotransferase 

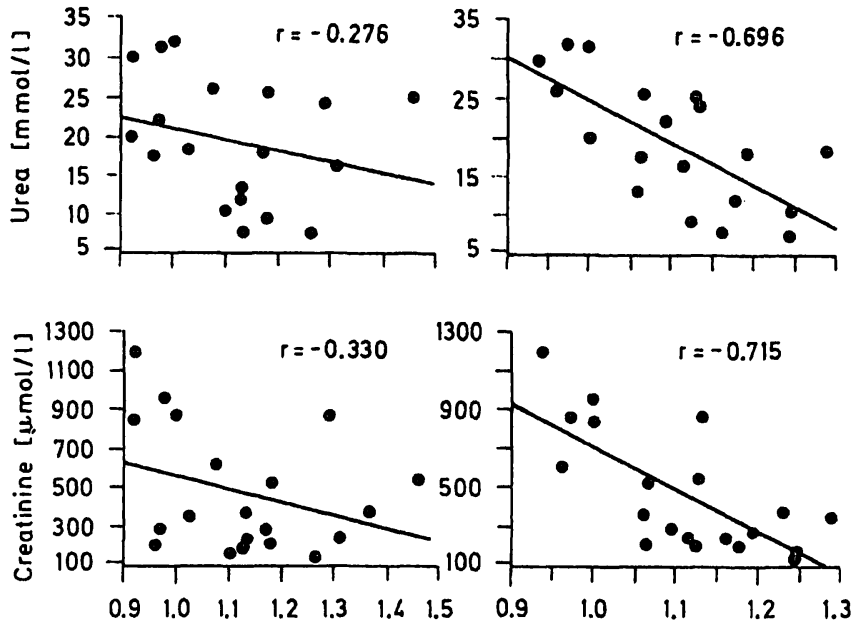

Alanine aminotransferase catalytic concentration fraction

Aspartate aminotransferase catalytic concentration fraction

Fig. 2. Statistical correlation between the concentrations of urea, creatinine and stimulation (activation) of the catalytic concentrations of alanine aminotransferase and aspartate aminotransferase by added pyridoxal $5^{\prime}$ phosphate in sera of patients with undialysed renal insufficiency. activity (not of alanine aminotransferase), although these patients show a significant decrease of pyridoxal 5 '-phosphate concentration in blood (fig. 1). The mechanisms by which urea or creatinine (or other parameters accumulating in uraemic sera) influences negatively the pyridoxal 5'-phosphate-induced aspartate aminotransferase activation needs further clarification. Possibly, conformational changes of the apoaminotransferases in highly uraemic sera might hinder the binding of the coenzyme to the protein moiety of the aminotransferase. Alternatively, pyridoxal 5'-phosphate could be trapped and/or degraded (hydrolysed) by certain compounds that increase in uraemic sera, and thereby be rendered unavailable to the apoenzyme.

Furthermore, differences in the isoenzyme pattern of aspartate aminotransferase in serum under these conditions might contribute to the effects described. It has been reported that the mitochondrial fraction of aspartate aminotransferase must be preincubated with pyridoxal $5^{\prime}$-phosphate longer than the cytosolic fraction to attain maximal activation (22).

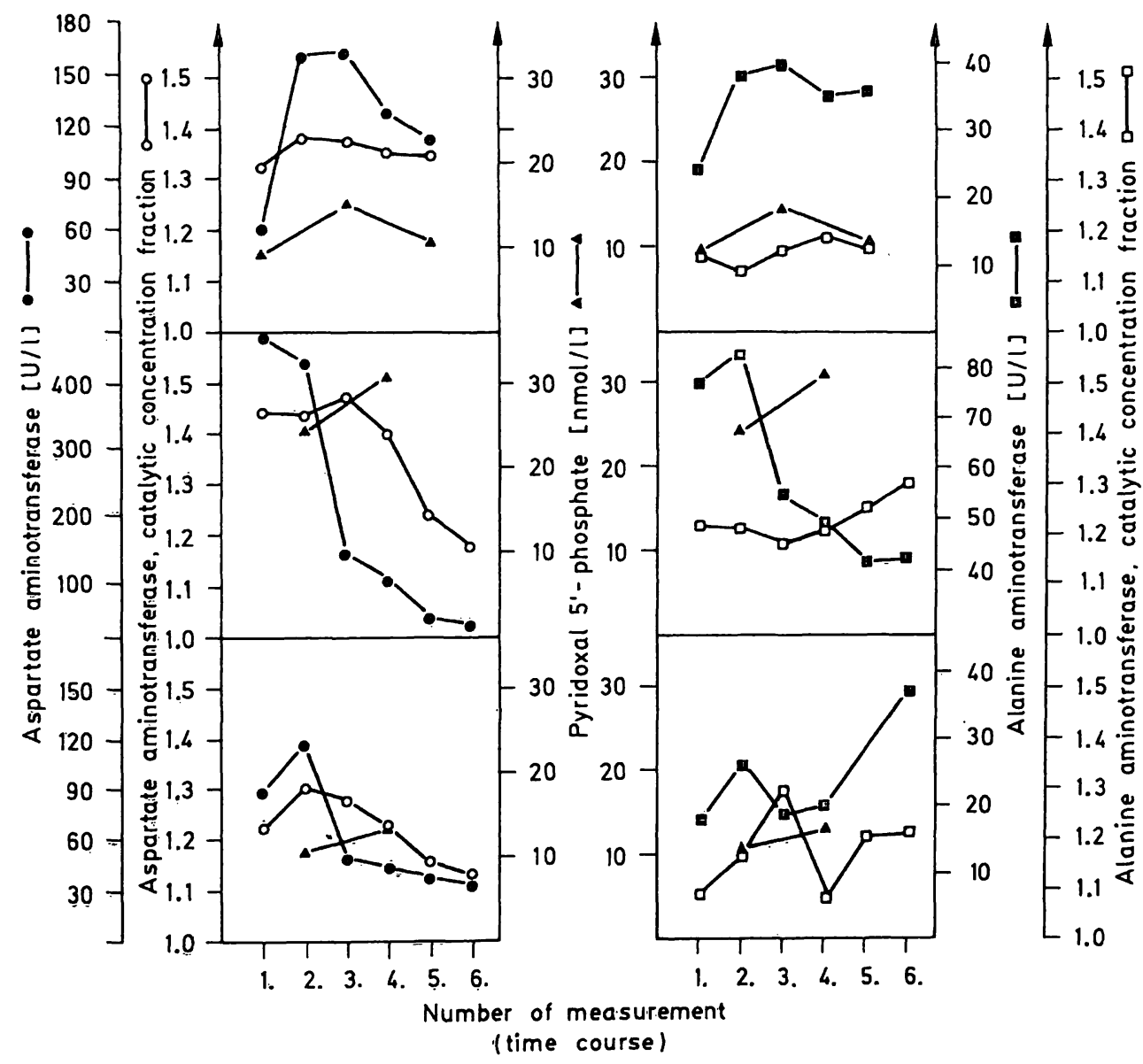

Fig. 3. Follow up of the catalytic concentrations of aspartate aminotransferase and alanine aminotransferase, their degrees of stimulation by pyridoxal $5^{\prime}$-phosphate, and the concentrations of pyridoxal $5^{\prime}$-phosphate in sera and plasma of 6 patients with acute myocardial infarction.

The time interval between the measurements is two to three days beginning with the first measurement after hospital admission. 
Whereas the patients described above have activities of transaminases within the reference ranges, similar studies were performed in individuals afflicted with acute myocardial infarction, and these patients possessed elevated levels of both transaminases. It is demonstrated in table 1 that the apoenzyme content of aspartate aminotransferase is significantly enhanced in these patients, which is also true, but less pronounced, for alanine aminotransferase. Transaminase activity, pyridoxal $5^{\prime}$-phosphate-induced stimulation, and pyridoxal 5'-phosphate concentration in plasma were followed up in patients with myocardial infarction of which some examples are shown in figure 3. The degree of pyridoxal 5'-phosphateinduced stimulation of aspartate aminotransferase activity changes during the course of the disease in loose parallelism to total aspartate aminotransferase activity. The changes occur independently of the fluctuations of pyridoxal $5^{\prime}$-phosphate in plasma. With respect to alanine aminotransferase the degree of stimulation by pyridoxal 5 -phosphate and total activity vary independently of each other and of the level of pyridoxal phosphate in blood (fig. 3). As an example, alanine aminotransferase activation might increase in spite of a pronounced fall of total alanine aminotransferase activity (right middle graph in fig. 3) or the degree of activation can change 3-fold without accompanying changes in total alanine aminotransferase activity (right, lower graph in fig. 3). Briefly summarized, the results obtained from myocardial infarction indicate for aspartate aminotransferase a weak positive statistic correlation $(r=0.590)$ between total enzyme activity and apoenzyme content or degree of pyridoxal phosphate-induced catalytic activation. Alanine aminotransferase behaves differently from aspartate aminotransferase because the respective parameters of alanine aminotransferase correlate only with $r=0.290$.

After finishing this study a report was published, which also failed to show an inverse relationship between the concentrations of plasma pyridoxal 5'phosphate and the percentage stimulation of the catalytic activities of aspartate aminotransferase and alanine aminotransferase, respectively (30). Thus, our results confirm this lack of correlation.

\section{References}

1. Snell, E. E. \& Dimari, S. J. (1970) Schiff base intermediate in enzyme catalysis. In: The Enzymes II (Boyer, P. D., ed.) Academic Press, New York and London, pp. 335-370.

2. Lumeng, L. \& Li, T. K. (1974) J. Clin. Invest. 53, 693-704.

3. Rossouw, J. E., Labadarios, D. \& Davis, M. (1978) S. Afr. Med. J. 53, 436-438.

4. Lacour, B., Parry, C., Drücke, T., Touam, M., Kreis, H., Bailly, M. \& Durand, D. (1983) Clin. Chim. Acta 127, $205-215$.

5. Lustig, V. \& Patten, R. (1976) Clin. Chim. Acta 69, $101-103$.

6. Hambelt, A. (1966) Scand. J. Clin. Lab. Invest. 18, Suppl. $92,181-188$.

7. Ury, A. G. \& Chassy, J. R. (1973) Clin. Chem. 19, $140-141$.

8. Rosalki, S. B. \& Bayoumi, R. A. (1975) Clin. Chim. Acta $59,357-360$

9. Moss, D. W. (1976) Clin. Chim. Acta 67, 169-174.

10. Ratnaike, S. \& Moss, D. W. (1977) Clin. Chim.Acta 74, $281-288$.

11. Cheung, T. \& Briggs, M. H. (1974) Clin. Chim. Acta 54, 127-129.

12. Garber, C. C., Feldbruegge, D. H. \& Hoessel, M. (1981) Clin. Chem. 27, 614-619.

13. Hørder, M. \& Bowers, G. N. (1977) Clin. Chem. 23, $551-554$.

14. Recommendations of the German Society for Clinical Chemistry (1972) Z. Klin. Chem. Klin. Biochem. 10, $281-291$.

15. Bergmeyer, H. U., Hørder, M. \& Moss, D. W. (1977) J. Clin. Chem. Clin. Biochem. 15, 719-720.
16. Bergmeyer, H. U. \& Hørder, M. (1980) J. Clin. Chem. Clin. Biochem. 18, 521 - 534.

17. Hørder, M., Moore, R. E. \& Bowers, G. N. (1976) Clin. Chem. 22, 1876-1883.

18. Ludwig, S. \& Kaplowitz, N. (1980) Gastroenterology 79, 545-549.

19. De Waal, A., Le Roux, S., Potgieter, G. M., Barnard, H. C. \& Schoombie, E. M: S. P. (1980) Clin. Chim. Acta $122,395-401$

20. Garber, C. C., Hoessel, M., Wallendal, J. \& Sarnat, G. (1981) Clin. Chem. 27, 1035.

21. Bruns, D. E., Savory, J., Titheradge, A. C., Cross, R. E. \& Wills, M. R. (1981) Clin. Chem. 27, 156-159.

22. Kamei, S., Ohkubo, A. \& Yamanaka, M. (1979) Clin. Chim. Acta 96, 98-105.

23. Westerhuis, L. W. J. J. M. \& Hafkenscheid, U. C. M. (1983) Clin. Chem. 29, 789-792.

24. Camp, V. M., Chipponi, J. \& Faraj,B. A. (1983) Clin. Chem. 29, 642-644.

25. Hamfelt, A. (1967) Scand. J. Lab. Invest. 20, 1-10.

26. Sachs, L. (1972) Statistische Auswertungsmethoden 3. ed. Springer, Berlin.

27. Coburn, S. P. \& Mahuren, J. D. (1983) Anal. Biochem. 129, $310-317$

28. Chabner, B. \& Livingston, D. (1970) Anal. Biochem. 34, 413-423.

29. Hontz, A. C., György, P., Balin, H., Rose, C. S. \& Shaw, D. L. (1974) Am. J. Clin. Nutr. 27, 440.

30. Hafkenscheid, J. C. M., Rosier, J. G. M. C. \& van Dijk, C. M. C. E. (1984) Clin. Chim. Acta $144,137=144$.

Prof. Dr. A. M. Gressner

Klinikum der Philipps-Universität

Abt. für Klinische Chemie und

Zentrallaboratorium

Baldingerstraße

D-3550 Marburg (Lahịn) 